\title{
MODEL PENDIDIKAN KARAKTER BERBASIS KEARIFAN LOKAL PADA SEKOLAH DASAR DI BANTUL YOGYAKARTA
}

\author{
Rukiyati dan L. Andriani Purwastuti \\ Fakultas Ilmu Pendidikan Universitas Negeri Yogyakata \\ email: rukiyati@uny.ac.id
}

\begin{abstract}
Abstrak: Tujuan penelitian ini adalah untuk menemukan model pendidikan karakter melalui lagu tradisonal Jawa; mendeskripsikan strategi penanaman nilai dalam model pendidikan karakter melalui lagu tradisional Jawa pada taman kanak-kanak di Daerah Istimewa Yogyakarta, Indonesia. Penelitian ini merupakan penelitian pengembangan tahap implementasi dengan tahapan: (1) pelaksanaan rencana kegiatan harian pembelajaran karakter; (2) analisis data proses pembelajaran; (3) evaluasi dan revisi rencana kegiatan harian dan praktek pembelajaran; (4) praktek pembelajaran dan menemukan model pendidikan karakter melalui lagu tradisional Jawa di Taman Kanak-Kanak. Hasil Penelitian menunjukkan bahwa para guru telah dapat menerapkan strategi penanaman nilai untuk pendidikan karakter melalui lagu tradisional Jawa. Lagu tradisional Jawa telah dinyanyikan dengan gerakan permainan anak didik bersama guru. Nilai-nilai yang terkandung di dalam lagu tradisonal Jawa telah ditanamkan oleh para guru dan dapat dipahami dengan baik oleh peserta didik, yaitu (1) lagu gundulgundul pacul (baik, rendah hati, tanggung jawab); (2) sluku-sluku bathok (cinta kepada Tuhan, taat beribadah, dermawan, kerjasama; (3) jaranan (hormat dan sopan santun, tanggung jawab, kedisiplinan, kerjasama); (4) menthog-menthog (baik dan rendah hati, kedamaian, percaya diri); (5) Lir-Ilir (cinta kepada Tuhan, tanggung jawab dan disiplin; (6) Kidang Talun (tata cara makan, berdoa sebelum makan); (7) Padang Bulan (tidak tidur sore-sore, kerja sama) dan (8) Dondong Apa Salak (taat pada orang tua, tidak rewel dan tidak nakal).
\end{abstract}

Kata Kunci: pendidikan karakter, penanaman nilai, lagu tradisional Jawa

\section{A MODEL OF CHARAKTER EDUCATION BASED ON LOCAL EDUCATION WISDOM AT ELEMENTARY SCHOOL IN BANTUL}

\begin{abstract}
This research aimed to find a character education model through traditional Javanese songs; to describe the value nurturance strategy in the character education model through traditional Javanese songs at kindergartens in Yogyakarta Special Territory, Indonesia. This was a research and development study at the implementation stage with the steps of: (1) the implementation of daily activity plan for the character nurturance; (2) analysis of teaching and learning process data; (3) evaluation and revision of the daily activity plan and the practice of teaching and learning; (4) the teaching and learning practice and finding the model of character education through the use of traditional Javanese songs at kindergartens. The results showed that the teachers were already able to implement the value nurturance strategy for character education through the use of traditional Javanese songs. The traditional Javanese songs were sung accompanied by game moves of the students and the teacher. The values contained in the traditional Javanese songs were already established by the teachers and could be well understood by the learners, namely the songs of: (1) Gundul-gundul pacul (the character of kindness, humbleness, responsibility); (2) Sluku-sluku bathok (loving God, obedience in serving God, generosity, cooperation); (3) Jaranan (respect and politeness, responsibility, discipline, cooperation); (4) Menthog-menthog (kindness and humbleness, peace, self-confidence); (5) Lir-ilir (loving God, responsibility and discipline); (6) Kidang talun (table manner, praying before eating); (7) Padang bulan (not going to bed too early, cooperation); and (8) Dondong apa salak (obeying parents, not fussy and not naughty).
\end{abstract}

Keywords: character education, value nurturance, traditional Javanese song 


\section{PENDAHULUAN}

Sebagai wahana utama dalam pembangunan bangsa dan watak (nation and character building), pendidikan dituntut untuk memberikan perhatian yang sungguhsungguh terhadap pengembangan diri manusia Indonesia dalam keseluruhan dimensinya. Dimensi-dimensi yang dimaksud adalah sejalan dengan hakikat kodrat manusia, yaitu manusia sebagai makhluk monodualis, dilihat dari aspek susunan kodrat (makhluk berjiwa-raga), sifat kodrat (makhluk individual/berpribadi dan makhluk sosial), kedudukan kodrat (makhluk otonom/mandiri, dan sekaligus makhluk ber-Tuhan). Pengembangan ketiga aspek ini hanya dapat dilakukan apabila manusia sejak awal kelahirannya telah dididik untuk mengarah pada teraktualisasikan potensi kodrat tersebut. Dengan cara ini, diyakini bahwa pendidikan akan memberi kontribusi yang nyata dan bermakna dalam mendukung pembangunan karakter bangsa secara keseluruhan yang menjadi agenda besar negara R.I. Perspektif pembangunan pendidikan tidak hanya ditujukan untuk mengembangkan aspek intelektual saja melainkan juga watak, moral, sosial dan fisik perserta didik, atau dengan kata lain menciptakan manusia Indonesia seutuhnya.

Pendidikan karakter mempunyai kaitan erat dengan komponen-komponen: pengetahuan moral tradisi, penalaran moral, belas kasih dan altruisme, serta kecenderungan moral. Lickona (Kirschenbaum, 1995:28) menggambarkan kecenderungan moral meliputi berhati nurani, mencintai kebaikan, dapat menguasai diri, rendah hati, kebiasaan moral dan kehendak baik (will). Lickona (www.cortland.edu/character/articles) juga mengatakan bahwa pendidikan karakter adalah upaya mengembangkan kebajikan sebagai fondasi dari kehidupan yang berguna, bermakna, produktif dan fondasi untuk masyarakat yang adil, penuh belas kasih dan maju. Karakter yang baik meliputi tiga komponen utama, yaitu: moral knowing, moral feeling, moral action. Moral knowing meliputi: sadar moral, mengenal nilai-nilai moral, perspektif, penalaran moral, pembuatan keputusan dan pengetahuan tentang diri. Moral feeling meliputi: kesadaran hati nurani, harga diri, empati, mencintai kebaikan, kontrol diri dan rendah hati. Moral action meliputi kompetensi, kehendak baik dan kebiasaan.

Sejalan dengan Lickona, Ryan dan Bohlin (1999:5) mengatakan bahwa karakter mengandung tiga unsur pokok, yaitu mengetahui kebaikan (knowing the good), mencintai kebaikan (loving the good) dan melakukan kebaikan (doing the good). Dalam pendidikan karakter, kebaikan itu seringkali dirangkum dalam sederet sifat-sifat baik (mulia). Dengan demikian, pendidikan karakter adalah sebuah upaya membimbing perilaku manusia menuju nilainilai kehidupan. Upaya ini juga memberi jalan untuk menghargai persepsi dan nilainilai pribadi yang ditampilkan peserta didik, baik di rumah, sekolah maupun di lingkup masyarakat yang lebih luas. Fokus pendidikan karakter adalah pada tujuantujuan etika, tetapi praktiknya meliputi penguatan kecakapan-kecakapan yang penting yang mencakup perkembangan sosial peserta didik.

Zuchdi (2010:35) mengatakan bahwa pendidikan karakter bersifat menyeluruh ataukomprehensif, menyangkut banyak aspek yang terkait menjadi satu kesatuan. Pendidikan karakter yang bertumpu pada strategi tunggal sudah tidak memadai untuk dapat menjadikan peserta didik memiliki moral yang baik. Oleh karena itu, diperlukan berbagai pendekatan yang oleh 
Kirschenbaum disebut pendekatan komprehensif. Istilah komprehensif dalam pendidikan karakter mencakup berbagai aspek: isi, metode, proses, subjek, evaluasi. Zuriah (2008:27) secara lebih terperinci mengatakan bahwa isi atau materi pendidikan karakter dapat dikelompokkan ke dalam tiga hal nilai akhlak, yaitu akhlak terhadap Tuhan Yang Maha Esa (mengenal Tuhan sebagai pencipta dan sifat-sifat-Nya, beribadah kepada Tuhan Yang Maha Esa, meminta tolong kepada-Nya), akhlak terhadap sesama (diri sendiri, orang tua, orang yang lebih tua, teman sebaya, orang yang lebih muda), dan akhlak terhadap lingkungan (alam baik flora maupun fauna dan sosialmasyarakat).

Pada penelitian Davidson, dkk (2007: 4) ditemukan adanya peran karakter dalam semua jenis prestasi sekolah, baik kurikuler maupun nonkurikuler. Penelitian ini dilakukan di 24 sekolah yang baik di Amerika Serikat. Hasil penelitian disimpulkan bahwa karakter terdiri dari dua bagian besar: karakter kinerja (performance character) dan karakter moral (moral character). Karakter kinerja terdiri dari semua nilai yang membuat seseorang mampu untuk mencapai aktualisasi potensi yang sangat tinggi dalam lingkungan kinerja (di kelas atau tempat kerja). Penelitian yang dilakukan oleh Benninga, dkk. (2003:19-31) mengenai hubungan antara implementasi pendidikan karakter dan prestasi akademik di sekolahsekolah dasar di California, Amerika Serikat menyimpulkan bahwa sekolah-sekolah dasar yang melaksanakan pendidikan karakter secara serius dan dirancang dengan baik cenderung memiliki prestasi akademik yang tinggi.

Sebagai bangsa yang Bhinneka Tunggal Ika, sebenarnya Indonesia mempunyai banyak tradisi dan nilai-nilai kearifan lokal yang perlu untuk dilestarikan dan dikem- bangkan agar karakter dan ciri khas manusia Indonesia dengan berbagai nilai budayanya tidak hilang begitu saja seiring pengaruh-pengaruh negatif budaya materialisme dan individualisme. Banyak tradisi dan nilai-nilai lokal justru menjadi kekuatan yang sangat penting dalam kerangka ketahanan kehidupan berbangsa bernegara Indonesia di era globalisasi dan era informasi saat ini.

Kuntoro (2012:6) mengatakan bahwa kata kearifan lokal digunakan untuk mengindikasikan adanya suatu konsep bahwa dalam kehidupan sosial-budaya lokal terdapat suatu keluhuran, ketinggian nilainilai, kebenaran, kebaikan dan keindahan yang dihargai oleh warga masyarakat sehingga digunakan sebagai panduan atau pedoman untuk membangun pola hubungan di antara warga atau sebagai dasar untukmembangun tujuan hidup mereka yang ingin direalisasikan. Nilai-nilai kearifan lokal dapat dijadikan sebagai basis bagi pendidikan karakter di sekolah. Wahab (2012: 18) mengatakan bahwa masyarakat pendukung nilai-nilai budaya dan beberapa di antaranya dapat dikategorikan sebagai local genius atau local knowledge dapat menjadi sumber nilai bagi masyarakat pendukungnya. Nilai-nilai budaya yang sudah dianggap baik berupa kearifan lokal dijadikan materi atau sumber materi pendidikan.

Sayangnya, nilai-nilai kearifan lokal tersebut belum secara serius masuk dalam agenda perbaikan pendidikan nasional. Keseragaman materi pelajaran masih tampak disekolah-sekolahwalaupun sudah ada kurikulum muatan lokal. Oleh karena itu, diperlukan adanya kreativitas dan inovasi untuk mengintegrasikan nilai-nilai kearifan lokal dalam proses pembelajaran di sekolah dengan payung pendidikan karakter bangsa. 
Guru adalah ujung tombak pendidikan formal (sekolah) yang berperan sangat penting dalam membangun karakter siswa. Untuk itu, guru haruslah menjadi pendidik yang profesional. Undang-Undang Nomor 14 Tahun 2005 tentang Guru dan Dosen mensyaratkan empat kompetensi yang harus dimiliki oleh guru profesional, yaitu kompetensi kepribadian, kompetensi sosial, kompetensi pedagogik, dan kompetensi profesional (akademik). Hidayatullah (2010: 152-153) mengatakan bahwa guru harus kayahati. Artinya, guru harus memiliki jiwa yang besar, lapang dada dan sabar dalam menghadapi siswa. Yang pertama kali dilakukan guru dalam pembelajaran adalah mengetuk dan menyentuh siswanya, di samping guru juga mengajar dengan melibatkan hatinya. Sekiranya guru bersikap keras lagi berhati kasar, tentu siswa akan menjauhinya.

Pendidikan karakter untuk anak usia sekolah dasar ditekankan untuk menggunakan konsep pembelajaran tematik-integratif dalam praksisnya. Pembelajaran tematik-integratif sering juga disebut pembelajaran terpadu. Dressel (Indrawati, 2009:17) mengatakan bahwa dalam kurikulum terpadu (interdisipliner), pengalaman pembelajaran yang telah direncanakan tidak hanya membekali siswa dengan pandangan terpadu mengenai pengetahuan umum (melalui pembelajaran model, sistem, dan struktur kebudayaan), tetapi juga memotivasi dan mengembangkan kekuatan pembelajar untuk memahami hubungan-hubungan baru dan menciptakan model, sistem dan struktur baru. Jacobs (Indrawati, 2009:18) mengartikan kurikulum interdisipliner sebagai pandangan mengenai pengetahuan dan pendekatan kurikula yang menerapkan metodologi dan bahasan dari lebih dari satu disiplin ilmu untuk mengkaji tema, isu, permasalahan, topik, atau pengalaman sentral. Intinya, pembelajaran tematik-integratif dalam kurikulum terpadu digunakan agar peserta didik mempunyai pemahaman yang utuh mengenai kenyataan, baik kenyataan sosial maupun alamiah yang mengelilingi kehidupannya.

Dalam penelitian Hajaroh, dkk. (2013) ditemukan beberapa hal, di antaranya pendekatan tematik-integratif dalam pendidikan karakter yang diimplementasikan di TK dapat dilaksanakan dengan mengadopsi sebagian dari nilai-nilai budaya lokal sebagai bahan ajar pendidikan karakter. Temuan tersebut telah memunculkan keinginan peneliti untuk merekonstruksi suatu model pembelajaran yang bersifat tematik-integratif pendidikan karakter, tetapi dengan memasukkan nilai-nilai kearifan lokal bagi sekolah-sekolah yang ada di pedesaan, khususnya di wilayah Bantul sehingga menjadi model pembelajaran yang berbeda dengan yang dikembangkan selama ini sebagai upaya untuk memantapkan profesionalitas guru dan pengembangan mutu sekolah. Berdasarkan beberapa pelatihan selama tahun 2011 dan 2012 bersama guru-guru di Bantul dapat diketahui bahwa banyak potensi kearifan lokal yang dapat dikembangkan oleh para guru, tetapi mereka perlu pendampingan untuk pengembangan diri sebagai guru profesional. Persoalan pokok dalam penelitian ini adalah bagaimana mengembangkan model pembelajaran tematik-integratif pendidikan karakter berbasis nilai-nilai kearifan lokal pada sekolah dasar di Bantul Yogyakarta?

\section{METODE}

Metode penelitian dirancang dengan pendekatan penelitian dan pengembangan model Borg dan Gall (Sukmadinata, 2015: 169) dengan sepuluh langkah penelitian. Penelitian ini telah menerapkan langkah-langkah atau tahapan yang harus dilakukan, 
Tabel 1. Tahapan Pengumpulan Data

\begin{tabular}{|c|c|c|c|}
\hline No. & Tahap & Metode Pengumpulan Data & Metode Analisis Data \\
\hline 1. & $\begin{array}{l}\text { Identifikasi nilai-nilai kearifan } \\
\text { lokal }\end{array}$ & FGD, observasi & Deskriptif kualitatif \\
\hline 2. & $\begin{array}{l}\text { Merancang draf desain pembe- } \\
\text { lajaran }\end{array}$ & Eksplorasi, wawancara & $\begin{array}{l}\text { Analisis isi, deskriptif } \\
\text { kualitatif }\end{array}$ \\
\hline 3. & $\begin{array}{l}\text { Pengembangan draf modul } \\
\text { pembelajaran }\end{array}$ & Eksplorasi, wawancara & $\begin{array}{l}\text { Analisis isi, deskriptif } \\
\text { kualitatif }\end{array}$ \\
\hline & Uji coba lapangan awal & observasi dan angket & $\begin{array}{l}\text { Deskriptif kuantitatif } \\
\text { dan kualitatif }\end{array}$ \\
\hline & Revisi hasil uji coba & $\begin{array}{l}\text { Dokumentasi rekaman pem- } \\
\text { belajaran dan wawancara }\end{array}$ & $\begin{array}{l}\text { Deskriptif kualitatif, } \\
\text { analisis isi }\end{array}$ \\
\hline
\end{tabular}

tetapi baru sampai penyempurnaan uji coba lapangan (tahap ketujuh).

Penelitian ini dilakukan dengan menggunakan berbagai metode pengumpulan dan analisis data dilakukan sebagaimana tampak pada Tabel 1.

\section{HASIL DAN PEMBAHASAN Hasil Penelitian}

Produk yang dihasilkan dalam penelitian ini adalah modul pendidikan karakter berbasis kearifan lokal untuk digunakan oleh guru sekolah dasar, khususnya guru kelas IV. Selain itu, dihasilkan pula CD pendidikan karakter berbasis kearifan lokal untuksiswaSD kelas IV dengan materi pembelajaran karakter terintegrasi dalam permainan Cublak-cublak Suweng, Lagu Gundhul-gundhul Pacul, dan dalam Membatik Cap pada Celengan Gerabah. Modul dan CD pembelajaran belum sampai tahap final, masih memerlukan penyempurnaan. Hal tersebut karena adanya berbagai kendala, terutama waktu dan biaya.

Hasil penelitian pada setiap langkah yang telah ditempuh adalah sebagai berikut.

\section{Penelitian dan Pengumpulan Data}

Hasil penelitian ditemukan bahwa banyak sekali kearifan lokal yang telah di- kembangkan oleh masyarakat di Pajangan Bantul, seperti batik (kain dan kayu), kuliner, upacara adat, seni karawitan, hadrah, yang semuanya merupakan warisan nenek moyang sehingga daerah sekitar Pajangan, Bantul terkenal sebagai daerah wisata batik dan wisata kuliner. Dalam konteks pendidikan, kearifan lokal telah menjadi fokus perhatian pemerintah daerah. Instruksi Bupati Bantul telah menetapkan bahwa kurikulum KTSP yang di dalamnya terdapat mata pelajaran muatan lokal pada masingmasing sekolah telah diseragamkan dengan menjadi Pendidikan Batik. Di samping itu, sekolah juga dapat mengembangkan muatan lokal yang lain, seperti seni karawitan, seni hadrah, pengolahan makanan lokal, permainan tradisional dan lain-lain. Berdasarkan studi literatur dan hasil Focus Discussion Group dengan para guru sekolah dasar (kelas IV dan V) se-UPTD Pajangan telah diindentifikasi bahwa kearifan lokal yang dikembangkan menjadi kurikulum muatan lokal di sekolah dasar baru terbatas pada transfer aspek keterampilan, belum sampai pada transfer aspek nilai-nilai luhur yang terkandung di dalamnya. Di sisi lain, guru juga masih bingung untuk mengembangkan pendidikan karakter sebagaimana telah dijadikan program pendidikan secara nasional. Kurangnya sosialisasi 
dan pelatihan-pelatihan menyebabkan guru dan masing-masing sekolah menginterpretasikan dan bertindak sendiri-sendiri dalam implementasinya. Dengan adanya FGD, guru-guru merasa sangat terbantu dalam wawasan pendidikan karakter dan kearifan lokal yang perlu diwariskan kepada peserta didik. Hasil FGD memunculkan kesepakatan bahwa perlu ada pendidikan karakter berbasis kearifan lokal di sekolah-sekolah dasar di Pajangan, Bantul agar peserta didik menjadi orang yang berkarakter mulia.

\section{Perencanaan}

Pada tahapini peneliti menyusun rencana penelitian, meliputi persiapan kemampuan-kemampuan yang diperlukan dalam pelaksanaan penelitian, rumusan tujuan yang hendak dicapai dengan penelitian tersebut, dan langkah-langkah untuk mengembangkan model pembelajaran berdasarkan hasil FGD dengan guru-guru, serta observasi di salah satu sekolah dasar yang telah berhasil melaksanakan pembelajaran muatan lokal (pendidikan batik, seni karawitan, pengolahan pangan lokal, permainan tradisional) dengan sangat baik.

\section{Pengembangan Draf Produk}

Pada tahap ini, telah dikembangkan bahan pembelajaran dalam bentuk RPP dan instrumen evaluasi serta draf modul pembelajaran yang akan dilaksanakan oleh guru dalam tahap selanjutnya.

Terdapat 6 orang guru yang bersama tim peneliti melakukan rancangan model pembelajaran yang akan diujicobakan di sekolah. Selain itu, juga disepakati 3 sekolah yang akan dijadikan uji coba lapangan, yaitu SD Triwidadi, SD Muh. Kalak Ijo, dan SD Guwosari. Pada saat workshop dan pertemuan selanjutnya telah diperoleh tiga rencana pelaksanaan pembelajaran (RPP) un- tuk diterapkan di tiga sekolah dengan melibatkan 6 orang guru kelas IV, yaitu (1) RPP Pendidikan Karakter terintegrasi dalam Pendidikan Batik dengan pokok bahasan: Pendidikan karakter kreatif, tekun dan bertanggung jawab terintegrasi dalam pembelajaran Membatik Celengan Gerabah; (2) Pendidikan karakter cinta ilmu, jujur, bertanggung jawab dalam pembelajaran lagu dolanan "Cublak-cublak Suweng" (mata pelajaran IPS); dan (3) Pendidikan karakter rendah hati, hati-hati dan kerja sama dalam pembelajaran lagu dolanan "Gundhul-gundhul Pacul" (mata pelajaran Seni, Budaya dan Keterampilan)

\section{Uji Coba Lapangan Awal}

Uji coba lapangan telah dilaksanakan oleh 6 orang guru dengan tiga pokok bahasan: (1) Pendidikan karakter cinta ilmu, jujur, bertanggung jawab dalam pembelajaran lagu dolanan "Cublak-cublak Suweng" (mapel IPS); (2) Pendidikan karakter kreatif, tekun dan bertanggung jawab terintegrasi dalam pembelajaran Membatik Celengan Gerabah; dan (3) Pendidikan karakter rendah hati, hati-hati dan kerja sama dalam gerak dan lagu "Gundhul-gundhul Pacul" (mapel SBK). Evaluasi pembelajaran dilakukan dengan tes, angket, refleksi siswa dan observasi penampilan guru. Secara keseluruhan proses pembelajaran telah berjalan dengan baik dan sesuai dengan yang direncanakan. Deskripsi proses pembelajaran pada waktu uji coba lapangan adalah sebagai berikut.

- Pendidikan Karakter terintegrasi dalam Lagu Dolanan"Cublak-cublak Suweng"

Pembelajaran dilaksanakan di SD Triwidadi, Pajangan, Bantul pada awal Oktober 2015. Ada dua orang guru yang melaksanakan pembelajaran, yaitu Bapak Irwan, S.Pd dan Ibu Marini, S.Pd. Siswa kelas IV berjumlah 28 orang, semuanya berpartisipasi aktif. Guru-guru berpakaian adat Jawa. 
Bapak Irwan memakai surjan sedangkan ibu Marini memakai kebaya dan kain jarik. Anak-anak hanya sebagian saja yang memakai baju adat, yang lain memakai baju seragam putih merah. Anak-anak tampak antusias. Sejak pagi mereka sudah siap di aula sekolah.

Pembelajaran dibuka oleh guru (Ibu Marini) dengan mengucap salam: "Assalammualaikum wa rahmatullahi wa barakatuh" (semua siswa beragama Islam) dan dijawab oleh siswa: "Waalaikum salam warahmatullahi wa barakatuh". Kemudian, guru mengajak anak-anak berdoa sebelum pelajaran. Setelah itu, guru melakukan appersepsi tanya jawab tentang makna Bhinneka Tunggal Ika. Anak-anak telah mengetahui maknanya dan dengan mudah dapat menjawab pertanyaan guru. Kemudian, guru mengajak siswa menyanyikan lagu wajib: Satu Nusa. Semua siswa dan guru bernyanyi bersama. Setelah bernyanyi, Bu Marini mengajak anak-anak untuk tepuk semangat diiringi yel-yel.

Setelah appersepsi, giliran Pak Irwan untuk menyampaikan pelajaran dengan mengajak anak-anak bermain "Cublak-cublak Suweng". Anak-anak dibagi menjadi 4 kelompok. Masing-masing kelompok bermain sambil bernyanyi: "Cublak-cublak suweng/ suwenge ting gelenter/ mambu ketundung gudel/ pak empong lera-lere/ sopo ngguyu ndelikkake/ sir-sir pong dhele gosong sir sir pong dhele gosong.

Anak-anak terlihat gembira pada permainan tersebut. Setelah bermain tiga kali, Pak Irwan menyampaikan pesan moral yang terkandung di dalam permainan dan makna lagu dolanan sebagai berikut.

"Anak-anak, permainan ini ada pesan moralnya, lagu Cublak-cublak Suweng itu ada maknanya. Sunan Giri yang memperkenalkan permainan ini kepada masyarakat.

- "Suweng itu apa?
+ "Anting", jawab seorang siswa perempuan.

- "Yaa benar". Suweng itu gambaran dari harta yang tak-ternilai, yaitu ilmu. Suwenge ting gelenter artinya ilmu itu tersebar di mana-mana. Semua orang wajib mencari ilmu. Mambu ketundung gudel artinya ilmu itu tercium (dapat diketahui) oleh siapa saja, tetapi orang bodoh (gudel) tidak akan mengetahuinya. Orang pintar mencari ilmu ke mana-mana. Sir pong dele gosong artinya orang kalau mencari ilmu hatinya harus bersih, harus konsentrasi. Jadi, anak-anak marilah kita mencari ilmu atau mencari harta itu dengan cara yang baik. Jangan seperti koruptor. Ibaratnya dia (koruptor) itu gudel. Jadi, dalam belajar harus dengan hati yang bersih. Cari ilmu itu untuk bekal nanti. Ayo tepuk semangat! Prok...prok...prok."

Setelah menjelaskan makna yang terkandung di dalam lagu Cublak-cublak Suweng, Pak Irwan menjelaskan simbol-simbol dari pakaian daerah Jawa yang dipakainya.

-“Ini namanya udeng atau iket (menunjuk ke arah kepalanya). Udeng maknanya mudeng. Iket artinya punya niat. Zaman dulu orang laki-laki rambutnya panjang. Rambut itu ibarat nafsu atau emosi, maka rambut itu disembunyikan dengan cara diiket. Lapis udeng itu ada 17, artinya jumlah ruku' dalam rakaat sholat. Tonojolannya ada di belakang, tidak di depan. Artinya, orang tidak boleh sombong, tidak boleh menonjolkan diri. Pakaian ini (menunjuk baju surjan) disebut rasukan, artinya agamanya merasuk dalam diri. Jarik artinya aja sirik, jangan iri hati. Keris diletakkan di bagian belakang (punggung). Keris melambangkan hal-hal keduniaan. Jadi, orang harus mengesampingkan halhal keduniaan, mengesampingkan harta benda. Orang yang sholat itu, dia meninggalkan hal-hal keduniaan. Arti lainnya adalah kalau ada masalah, orang harus mengedepankan musyawarah dalam 
memutuskan suatu perkara, jangan pakai senjata. Maka, senjata disembunyikan di belakang." (Obs. 12 Okt. 2015).

Setelah menjelaskan tentang ajaran moral dalam pakaian Jawa, guru melanjutkan dengan ajaran moral yang terkandung di dalam permainan "Cublak-cublak Suweng", bahwa permainan ini melatih anak untuk bekerja sama, jujur, tidak curang dalam bermain dan berperilaku lainnya, bertanggung jawab, berani. Anak-anak yang bermain harus ada kerjasama supaya dapat memerankan peran masing-masing dengan baik, tidak bisa bermain sendiri. Berani dibiasakan di dalam permainan ini karena anak yang jadi harus berani menebak batu di tangan anak yang mana dan jika tebakannya salah dia harus berani dan bertanggung jawab untuk jadi lagi. Anak yang memegang batu jika tertebak harus jujur mengatakan bahwa benar batu ada di tangannya, tidak bisa disembunyikan atau dibuang sehingga dia harus bertanggung jawab untuk menjadi anak yang jadi (yang menebak batu).

Setelah penjelasan dari Pak Irwan, pembelajaran diakhiri dengan refleksi. Pak Irwan menguatkan kembali hasil belajar yang telah dilaksanakan bersama bahwa kita harus menghargai budaya sendiri. Jangan sampai budaya kita diakui oleh bangsa lain. Jangan sampai lagu "Cublak-cublak Suweng" diakui negara lain. Tanamkan sifat-sifat jujur, berani, kerja sama, tanggung jawab dancari ilmu sebanyak-banyaknya, seperti pesan dalam lagu dan permainan "Cublak-cublak suweng".

Kemudian, Ibu Marini melakukan sedikit evaluasi pada anak-anak. Ibu Marini bertanya pada siswa yang ditunjuk. Mereka dapat menjawab dengan mudah bahwa sifat yang terdapat di dalam permainan $\mathrm{Cu}$ blak-cublak Suweng adalah jujur, kerjasama, dan tanggung jawab.
Sebelum pelajaran hari itu ditutup, Ibu Marini menugaskan anak-anak untuk membuat kliping tentang kebudayaan, dapat berupa kumpulan rumah adat, pakaian adat, tari daerah atau kombinasi dari semuanya. Setelah itu, bu Marini dan Pak Irwan mengajak anak-anak untuk tepuk semangat: prok...semangat belajar... sukses ... amiin. Kegiatan ditutup dengan berdoa dipimpin oleh seorang anak. Guru mengucap salam penutup dan dijawab oleh anakanak semua. Pelajaran berakhir.

- Pendidikan Karakter Terintegrasi dalam Pelajaran "Membatik Celengan Gerabah"

Kegiatan pembelajaran karakter terintegrasi dengan pelajaran Membatik Celengan Gerabah dilaksanakan di SD Muhammadiyah Kalak Ijo dengan dua orang guru, yaitu Ibu Dina dan Ibu Hesti Pramita Sari (dari SD Karebet). Sebagaimana telah dirancang di dalam RPP, pembelajaran hari itu adalah pendidikan karakter melalui pembiasaan. Mereka akan praktik nilai-nilai kreativitas, hemat, ketekunan, kerjasama, kebersihan dalam pembelajaran muatan lokal membatik celengan gerabah.

Pertama, Ibu Dina membuka kegiatan belajar dengan mengucap salam dan memimpin siswa berdoa. Setelah itu, ibu Dina memperkenalkan Ibu Hesti sebagai guru SD Karebet yang akan bersama-sama melaksanakan pembelajaran. Ibu Hesti mengajak serta dua orang murid SD Karebet. Tampak anak-anak sangat senang dan antusias belajar bersama teman dari sekolah lain.

Kegiatan appersepsi dilakukan. Bu Dina mengingatkan bahwa hari itu mereka akan belajar membatik celengan. Tampak peralatan membatik celengan berupa kuas, buah-buahan, dan cat sudah ada di atas meja. Tak lupa celengan gerabah sudah dicat dasar warna putih. Meja sudah dialasi 
koran dan kain agar anak-anak dapat membatik dengan leluasa, tetapi meja tidak kotor. Ini merupakan salah satu fasilitasi agar anak dapat mempraktikkan nilai kebersihan dalam berkarya.

Siswa diberi kebebasan untuk membuat pola batik sesuai kreasi masing-masing. Ada yang menggunakan cap buah belimbingyang telah dipotong sehingga membentuk bintang, ada pula yang membatik dengan cap wortel dan juga pelepah pisang. Untuk membuat titik-titik dalam membatik, anak-anak menggunakan kuas kecil dan spidol yang sudah habis tintanya. Kuas atau spidol dicelupkan ke dalam cat sesuai warna yang diinginkan dan digoreskan pada media celengan. Ada yang membatik bunga warna warni dengan titik-titik sebagai pola diagonal, ada pula yang dengan bebas membatik bunga-bunga berdasarkan cap dari buah-buahan yang telah tersedia. Di dalam proses membatik, guru juga memberi penguatan-penguatan berupa pujian dan semangat agar anak-anak dapat berkarya lebih baik.

Setelah sekitar 45 menit, proses membatik selesai. Celengan putih telah berubah menjadi lukisan batik warna-warni dengan pola tertentu. Siswa mengumpulkan hasil karya di atas meja di dekat papan tulis. Siswa yang belum selesai tetap diberi semangat oleh guru dan teman-temannya agar selesai.

Berbagai macam celengan batik sudah terkumpul di meja depan, kemudian Bu Dina dan Bu Hesti menilai karya siswa. Terpilihlah tiga celengan yang dinilai paling indah, yaitu yang dilukis dengan menggunakan campuran warna-warna lebih bervariasi dan rapi.

Selesai memberikan evaluasi karya yang menjadi juara 1, 2 dan 3, guru mengajak anak-anak untuk memberi tepuk tangan kepada ketiga anak yang menang se- bagai bentuk apresiasi, menghargai karya seni yang telah dihasilkannya. Untuk evaluasi lainnya, Bu Dina dan Bu Hesti memberi siswa tugas melakukan refleksi pengalamannya ketika membatik celengan gerabah. Selesai membuat refleksi, anak-anak mengumpulkannya kepada guru. Berikut beberapa hasil refleksi siswa.

"Aku sangat bahagia, gembira dengan pelajaran ini. Peristiwa yang menyenangkan sekali." (Elida/13/10/2015)

"Aku sangat senang sekali. Batiknya sangat susah kalau pakai cap. Kalau pakai kuas cepat." (Rindi/13/10/2015).

"Saat aku membatik, aku senang dan gembira. Seruuuu..., senang, gembira, agak sulit." (Nisa, 13/10/2015).

Setelah refleksi siswa dikumpulkan, Bu Dina menutup pelajaran dengan mengajak anak-anak berdoa penutup pelajaran.

Berdasarkan pelajaran yang telah dilaksanakan, dapat disimpulkan bahwa siswa telah belajar mempraktikkan nilai-nilai kreativitas, kesabaran, ketekunan, dan tanggung jawab. Anak-anak tampak senang. Mereka berkreasi mencap celengan dengan berbagai macam motif yang disukainya, tetapi juga mereka merasakan kesulitannya membatik cap dengan media buah-buahan dan pelepah pisang. Walaupun sulit, mereka dengan tekun dan sabar menyelesaikannya sebagai wujud karakter bertanggung jawab. Mereka juga mempraktikkan nilai kebersihan di dalam membuat batik celengan gerabah yang indah.

- Pendidikan Karakter Terintegrasi dalam Pelajaran "Gundhul-gundhul Pacul"

Kegiatan pembelajaran karakter terintegrasi dengan pelajaran Seni Budaya dan Keterampilan (SBK) dilaksanakan di SD Guwosari di bawah bimbingan Ibu Ari. Sebagaimana telah dirancang di dalam RPP, pembelajaran hari itu adalah pendidikan 
karakter melalui bermain peran dalam lagu "Gundhul-gundhul Pacul". Siswa kelas IV akan praktik nilai-nilai rendah hati (tidak sombong), kerjasama, dan tanggung jawab.

Ibu Ari membuka pelajaran dengan mengucap salam dan memimpin siswa berdoa. Setelah itu, Ibu Ari melakukan appersepsi dengan mengingatkan kembali pengetahuan siswa tentang berbagai macam lagulagu daerah. Ibu Ari bertanya kepada siswa tentang lagu dari berbagai daerah Aceh, Minangkabau, Sunda, Betawi, Jawa Tengah, dan lain-lain daerah. Siswa ada yang dapat menjawab dengan tepat, tetapi ada pula yang lupa. Kemudian, Ibu Ari mengoreksi jawaban siswa yang salah.

Setelah appersepsi, Bu Ari mengajak anak-anak untuk bermain peran dalam lagu Gundhul-gundhul Pacul. Beberapa anak laki-laki yang akan bermain peran sudah siap dengan pakaian Jawa berupa surjan kain jarik, dan blangkon. Anak-anak perempuan memakai kebaya dan jarik. Sebagian anak-anak yang lain hanya mengenakan seragam sekolah. Properti berupa bakul berisi butiran-butiran gabus (seolah-olah nasi dalam bakul) sudah disiapkan. Demikian pula caping (semacam topi berbentuk kerucut) telah disiapkan.

Bu Ari mengajak anak-anak bernyanyi lagu Gundhul-gundhul Pacul sambil bermain peran. Si Gundhul berada di tengah sambil membawa bakul berisi butiran nasi. Di sekelilingnya anak-anak yang berjalan berkeliling sambil mengikuti gerakan dan jalannya si Gundhul. Ketika si Gundhul "gembelengan" (berjalan dengan angkuh/sombong), bakul yang disungginya terjatuh dan nasi bertebaran ke tanah. Akhirnya, nasi menjadi mubazir, kotor tidak dapat dimakan.

Ketika bakul terjatuh dan nasi bertebaran, teman-teman si Gundhul memunguti nasi untuk dimasukkan ke dalam ba- kul tadi. Bu Ari mengatakan: "Itulah akibatnya kalau jadi orang yang gembelengan. Nasi tumpah dan sia-sia tidak dapat dimanfaatkan. Itu karena si Gundhul sombong, angkuh. Dia merasa sudah hebat. Tapi apa yang terjadi? Bakulnya malah gelimpang tho? Jadi, kita tidak boleh sombong yaa... Kalau orang sombong dia pasti celaka. Apalagi kalau jadi pemimpin. Dengan tingkah lakunya yang seperti itu, dia sudah merepotkan bawahannya. Itu artinya dia tidak bertanggung jawab. Maka, kita tidak boleh mengikuti sifat si Gundhul yang sombong itu yaa.", demikian penjelasan bu Ari. Anak-anak menjawab: "yaa bu". Setelah penjelasan bu Ari, anak-anak diajak bermain peran dan bernyanyi sekali lagi.

Pada akhir pelajaran, Bu Ari memberikan evaluasi pembelajaran berupa tes pilihan ganda untuk menilai kemampuan kognitif siswa tentang lagu-lagu daerah dan angket skala sikap untuk mengetahui aspek afektif siswa.

Secara umum, siswa sudah menguasai pengetahuan yang disampaikan dan sikapnya sudah setuju dengan nilai-nilai rendah hati, kerja sama dan tanggung jawab. Rata-rata nilai untuk tes adalah 70, sedangkan untuk aspek skala sikap diperoleh skor rata-rata: 3,2 (setuju).

Setelah evaluasi, bu guru memberikan penguatan bahwa sebagai manusia kita tidak boleh sombong. Orang yang sombong akan celaka dan membuat orang lain susah. Orang yang sombong berarti orang yang tidak bisa bekerja sama, seenaknya sendiri.

Dari pelajaran yang telah disampaikan oleh Bu Ari, dapat disimpulkan bahwa pendidikan karakter terintegrasi denganSBK pokok bahasan lagu “Gundhul-gundhul Pacul" telah dapat berjalan sesuai dengan rencana pembelajaran yang telah disusun. Nilai-nilai karakter telah dipahami oleh siswa dan dirasakan di dalam permainan 
dan nyanyian. Hal itu juga tampak di dalam evaluasi pembelajaran.

\section{Revisi Hasil Uji Coba Lapangan}

Berdasarkan hasil uji coba lapangan dilakukan perbaikan-perbaikan pada modul yang disusun terkait aspek penilaian. Pada saat proses pembelajaran telah berlangsung dengan baik sesuai dengan rancangan yang telah disusun. Hanya saja penilaian afektif pada pembelajaran "Membatik Cap pada Celengan Gerabah" kurang sistematis. Siswa hanya diberi tugas mengungkapkan perasaannya ketika membatik. Berdasarkan diskusi dengan ahli diperoleh hasil sebaiknya disiapkan angket skala sikap dan siswa diberi tugas mengisi angket tersebut sehingga hasil pembelajaran lebih terukur.

\section{Pembahasan}

Penelitian pengembangan model pendidikan karakter berbasis kearifan lokal baru selesai sebagian, yaitu sampai tahap 5 dari 10 tahap yang harus dilaksanakan. Walaupun demikian telah diperoleh beberapa hasil yang dapat dilaporkan.

Dalam penelitian ini telah dihasilkan modul pembelajaran yang memuat materi kearifan lokal yang dapat diintegrasikan dengan pendidikan karakter. Materi kearifan lokal tersebut untuk memperkaya materi mata pelajaran Pendidikan Batik, Seni Budaya dan Keterampilan serta mata pelajaran Ilmu Pengetahuan Sosial.

Uji coba pelaksanaan lapangan menunjukkan bahwa guru-guru telah berhasil melaksanakan pembelajaran yang mengintegrasikan pendidikan karakter berbasis muatan lokal pada mata-mata pelajaran tersebut. Pada awalnya, guru masih kesulitan menuangkan ide pendidikan karakter terintegrasi dalam muatan lokal terlihat dari kesulitan mereka membuat RPP. Dalam hal ini, penelilti dan guru pelaksana telah me- lakukan workshop dan komunikasi langsung maupun lewat email untuk merevisi RPP sehingga diperoleh RPP yang diinginkan.

Pelaksanaan pembelajaran pada tahap uji coba lapangan secara keseluruhan telah berjalan lancar. Guru-guru telah dapat melaksanakan pembelajaran sesuai dengan RPP yang disusun. Suasana pembelajaran juga tampak menyenangkan bagi siswa. Siswa juga telah dapat memahami nilai-nilai karakter yang dibelajarkan. Bukan sekedar memahami, siswa juga telah belajar mempraktikkan nilai-nilai karakter tersebut di dalam permainan tradisional, seni karawitan dan membatik sederhana pada media celengan. Hal mana sejalan dengan pernyataan Kirschenbaum (1995:27) bahwa pendidikan karakter mempunyai kaitan erat dengan komponen-komponen: pengetahuan moral tradisi, penalaran moral, belas kasih dan altruisme, serta kecenderungan moral. Upaya tersebut perlu diteruskan dari generasi tua kepada generasi muda agar mereka mempunyai kecenderungan moral meliputi berhati nurani, mencintai kebaikan, dapat menguasai diri, rendah hati, kebiasaan moral dan kehendak baik (will). Hal inilah yang dinyatakan Lickona (www.cortland.edu/ character/articles) bahwa pendidikan karakter adalah upaya mengembangkan kebajikan sebagai fondasi dari kehidupan yang berguna, bermakna, produktif dan fondasi untuk masyarakat yang adil, penuh belas kasih dan maju.

Pada pembelajaran karakter berbasis kearifan lokal yang telah dilaksanakan meliputi tiga komponen utama, yaitu moral knowing, moral feeling, moral action. Moral knowing meliputi: sadar moral, mengenal nilai-nilai moral, perspektif, penalaran moral, pembuatan keputusan dan pengetahuan tentang diri. Dari jawaban siswa diketahui bahwa pengetahuan moral siswa telah bertambah baik, demikian pula moral feeling 
telah mengarah kepada kesadaran hati nurani, mencintai kebaikan, kontrol diri dan rendah hati. Hanya saja moral action yang meliputi kompetensi, kehendak baik dan kebiasaan belum sepenuhnya diketahui karena pembelajaran kebiasaan dan kehendak baik yang dilaksanakan dalam penelitian ini baru sekali dilakukan, belum berulang-ulang. Harapan peneliti, guru akan meneruskan kegiatan pembelajaran karakter terintegrasi dengan kearifan lokal secara kontinyu. Jika guru konsisten mengintegrasikan pendidikan karakter ke dalam berbagai materi pelajaran, besar kemungkinan karakter siswa yang baik akan terbentuk pula dengan sendirinya.

Di dalam penelitian ini telah diungkap berbagai pembelajaran karakter yang melekat dalam kearifan lokal masyarakat Yogyakarta, tetapi sebenarnya masih sangat banyak nilai-nilai kearifan lokal yang terkandung di dalam materi muatan lokal Pendidikan Batik, Seni Karawitan, Lagu Dolanan yang dapat dijadikan materi pendidikan karakter pada pembelajaran selanjutnya. Hal tersebut sangat strategis dilakukan terlebih bila dikaitkan dengan kondisi bangsa Indonesia sekarang ini yang sering terombangambing dalam pusaran globalisasi di satu pihak dan nasionalisme Indonesia di lain pihak.

Transformasi budaya berbasis nilainilai kearifan lokal sebagaimana dinyatakan Adimihardja (via Sadjim, 2015:35) perlu direvitalisasi, dikembangkan isinya dan disesuaikan dengan perkembangan kehidupan sosial budaya masyarakat setempat. Selanjutnya, menjadi komitmen bersama dalam pemanfaatannya sebagai salah satu bentuk kohesivitas sosial kehdiupan masyarakat yang harmonis dalam kemajemukannya. Semboyan Bhinneka Tunggal Ika mendapatkan relevansinya berkaitan dengan revitali- sasi kearifan lokal agar bangsa Indonesia dapat tetap eksis dalam kemajemukannya.

\section{PENUTUP \\ Simpulan}

Sampai tahap lima dari sepuluh tahap yang harus dilakukan dalam penelitian pengembangan dapat disimpulkan bahwa modul pembelajaran yang telah dihasilkan memuat materi kearifan lokal yang dapat diintegrasikan dengan pendidikan karakter. Materi kearifan lokal tersebut untuk memperkaya materi mata pelajaran Pendidikan Batik, Seni Budaya dan Keterampilan serta mata pelajaran Ilmu Pengetahuan Sosial. Uji coba pelaksanaan lapangan menunjukkan bahwa guru-guru telah berhasil melaksanakan pembelajaran yang mengintegrasikan pendidikan karakter berbasis muatan lokal pada mata-mata pelajaran tersebut.

\section{Saran}

Penelitian ini perlu dilanjutkan sampai pada tahap selanjutnya, yaitu tahap pelaksanaan lapangan, penyempurnaan produk akhir, diseminasi dan implementasi sehingga produk yang dihasilkan berupa modul pendidikan karakter berbasis kearifan lokal untuk digunakan di sekolah dasar benar-benar dapat diwujudkan dan layak diimplementasikan.

\section{UCAPAN TERIMA KASIH}

Artikel ini dapat diselesaikan atas bantuan berbagai pihak, terutama saat dilaksanakannya penelitian. Selayaknya penulis mengucapkan terima kasih kepada: (1) Dekan FIP UNY beserta jajarannya yang telah memfasilitasi penelitian kami; (2) Bapak Lejaryono, S. Pd. (SD Sendangsari), Bapak Irwan, S. Pd. dan Ibu Marini, S. Pd. (SD Triwidadi), Ibu Andin, S. Pt (SD Muh. Kalak Ijo), Ibu Ria Merdekawuri (SD Guwosari), 
Ibu Happy Pramita Sari (SD Karebet), atas kerjasamanya dalam penelitian ini.

\section{DAFTAR PUSTAKA}

Benninga, JacquesS.etal. dkk. 2003. “The Relationship of Character Education Implementation and Academic Achieveent in Elementary Schools". Journal of Research in Character Education. September 2003, 1, 1, 19 -32. ProQuest Education Journals.

Davidson, Matthew, et.al. 2007. "Smart and Good Schools". Education Week November 2007. Diambil pada Tanggal 3 Maret 2008 dari: http://www.edweek.org/ew/articles/2007.

Indrawati 2009. Model Pembelajaan Terpadu di Sekolah Dasar untuk Guru SD. Diambil pada Tanggal 19 Januari 2011 dari www.p4tkipa.org.

Lickona, Thomas. 1991. Educating for Character - How our Schools Can Teach Respect and Responsibility. New York: Bantam Books.

Lickona, Thomas. 2008. Effective Character Education. Diambil pada Tanggal 20 Februari 2008 dari www.cortland.edu/character/articles/char_v.asp.

Hidayatullah, M. Furqon. 2010. Guru Sejati: Membangun Insan Berkarakter Kuat dan Cerdas. Surakarta: Yuma Pustaka.

Ryan, Kevin \& Karen E. Bohlin. 1999. Building Character in Schools - Practical Ways to Bring Moral Instruction to Life. San Fransisco: Jossey-Bass a Wiley Imprint.

Kirschenbaum, Howard. 1995. 100 Ways to Enhance Values and Morality in Schools and Youth Settings. Boston: Allyn and Bacon.

Kuntoro, Sodiq A. 2012. “Konsep Pendidikan Berbasis Kearifan Lokal sebagai Dasar Pembentukan Karakter Bangsa". Prosiding Seminar Nasional Ilmu Pendidikan. Program Studi Ilmu Pendidikan Program Pascasarjana Universitas Negeri Makassar.

Sukmadinata, Nana Syaodih. 2015. Metode Penelitian Pendidikan. Bandung: Program Pascasarjana UPI dan Remaja Rosdakarya.

Sadjim, Umar M. 2015. “Revitalisasi NilaiNilai Bhinneka Tunggal Ika dan Kearifan Lokal berbasis Learning Society Pascakonflik Sosial di Ternate". Ringkasan Disertasi. Program Pascasarjana Universitas Negeri Yogyakarta.

Wahab, Abdul Azis. 2012. "Pengelolaan Pendidikan Berbasis Kearifan Lokal". Prosiding Seminar Nasional Ilmu Pendidikan. Program Studi Ilmu Pendidikan Program Pascasarjana Universitas Negeri Makassar.

Zuchdi, Darmiyati. 2008. "Potret Pendidikan Karakter di Berbagai Jenjang Sekolah". Proceding Seminar dan Lokakarya Nasional Restrukturisasi Pendidikan Karakter. Yogyakarta: Universitas Negeri Yogyakarta.

Zuchdi, Darmiyati. 2010. Humanisasi Pendidikan - Menemukan kembali Pendidikan yang Manusiawi. Jakarta: Bumi Aksara. 